\title{
Contribution to the knowledge of three Indian Spermacoce L. (Rubiaceae) and some preliminary information about their pollination ecology
}

Aluri Jacob Solomon Raju \& Janga Radhakrishna

Department of Environmental Sciences, Andhra University, Visakhapatnam 530 003, India.

Correspondence

AJS. Raju

E-mail: solomonraju@gmail.com

Received: 10 February 2017

Accepted: 3 July 2017

Published on-line: 25 July 2017

\section{Resumen}

Contribución al conocimiento de tres especies indias de Spermacoce L. (Rubiaceae) e información preliminar de su ecología de polinización.

Se han descrito caracteres taxonómicos no documentados para Spermacoce hispida L. y Spermacoce articularis L. S. hispida es bimórfica. Las flores son débilmente protándrica, nectaríferas y auto-polinizadoras. Las mariposas, las abejas y los trips son importantes como polinizadores. El conjunto de fruta natural más elevado que se evidencia en estas especies se atribuye a autopolinización y entomofilia. Los frutos la dehiscencia es septicida en S. hispida y S. articularis, y circunscisa en Spermacoce pusilla Wall. La dispersión de las semillas es anemo-, baro-, ombro- e hidrocórica. Estas especies ocupan diferentes hábitats para evitar la competencia por los polinizadores y maximizar la producción de semillas y ampliar su rango de distribución.

Palabras clave: Bimorfismo, Taxonomía, Entomofilia, Dispersión de semillas.

\begin{abstract}
Undocumented taxonomic characters have been described for Spermacoce hispida L. and Spermacoce articularis L. S. hispida is bimorphic. The flowers are weakly protandrous, nectariferous and self-pollinating. Butterflies, bees and thrips are important as pollinators. The highest natural fruit set evidenced in these species is attributed to auto-selfing and entomophily. Fruits dehisce septicidally in S. hispida and S. articularis and circumscissile mode in Spermacoce pusilla Wall. Seed dispersal is anemo-, baro-, ombro- and hydro-chorous. These species occupy different habitats to avoid competition for pollinators and maximize seed output and expand their distribution range.
\end{abstract}

Key words: Bimorphism, Taxonomy, Entomophily, Seed dispersal. 


\section{Introduction}

Rubiaceae is one of the five largest plant families with 611 genera and 13,143 species (Davis et al. 2009). It is a cosmopolitan family, predominantly pantropical, and with a small portion of species of extra-tropical distribution. Almost one half of the species and one third of the genera occur in the Neotropics. The species of this family occur at all layers of tropical vegetation, with all kinds of habits, as herbs, shrubs, lianas, and from small trees to tall canopy trees (Delprete \& Jardim 2012). This family shows a wide spectrum of floral mechanisms characterized by different types of gynoecium and androecium organization (Castro \& Paulo-Eugenio 2001). Robbrecht (1988) reported heterostyly and secondary pollen presentation as reproductive mechanisms in this family. The sexual systems include hermaphroditism, monoecy, polygamomonoecy, dioecy and heterostyly. Coelho \& Barbosa (2003) mentioned that little is known about the reproductive biology of most species in this family, particularly from tropical regions. Robbrecht (1988) reported that pollination in this family is entomophilous and its mechanism is conspicuously specialized via stylar modifications for passive pollen presentation. Anderson (1973) reported that heterostyly in this family consists basically of a balanced polymorphism in which some plants bear flowers having the receptive stigmas above the level of the anthers (pin flowers) and the other plants bear flowers having the receptive stigmas below the anthers (thrum flowers). This difference is often accompanied by differences in corolla tube length, filament length, pollen and stigmatic papillae size.

In hermaphroditic isostylous flowers, protandry is predominant; the pollen matures early and is shed at or soon after anthesis. Before anthesis and in some cases for a period after anthesis, the elongation of the style is arrested, the immature stigmas are temporarily retained within the tube of the corolla, below the level of the anthers. During and/or after the release of the pollen the style elongates, eventually equalling or surpassing the anthers, and the stigmas belatedly mature. Puff $e t$ al. (2005) stated that protandry in isostylous flowers is associated with secondary pollen presentation. These authors recognized four types secondary pollen presentation according to the presenting area and receptive surfaces: (i) pollen deposition on the style only; (ii) pollen deposition on the style and outside of the non-receptive stigma lobes; (iii) pollen deposition on the outer side of the stigma; (iv) pollen deposition exclusively, largely or partly on the receptive surface of the stigma. In types (ii) and (iii), the receptive areas are the inner sides of the stigma lobes or the furrows between two stigma lobes. At the time of pollen deposition the stigma lobes are fused so that contact between self-pollen and the receptive surfaces is improbable. Yeo (1993) and Castro et al. (2008) suggested that protandry, herkogamy, and self-incompatibility are the primary means of avoiding self-interference in plants with secondary pollen presentation. Ladd (1994) stated the secondary pollen presentation has evolved to increase the efficiency and accuracy of pollen transfer because of the close proximity of pollen to the stigma while Webb \& Lloyd (1986) stated that the proximity of pollen and stigma, however, could result in self-interference. Castro et al. (2008) suggested that the mechanism of secondary pollen presentation might be an accurate system for pollen transport, but that it may also have its costs.

Rubiaceae species with a wide range of flower forms, sizes and colours present a wide range of floral visitors (Consolaro et al. 2005). Most of the pollinators include insects while birds and bats play a minor role in pollination. Among insects also, bees are important pollinators especially for small-flowered species; the showy large-flowered species are adapted for pollination by butterflies and hawk-moths. The butterflies are pollinators for scentless flowers while hawkmoths for longtubed fragrant flowers (Puff et al. 2005). Different workers documented that the family as a whole shows a great diversity of pollination syndromes involving butterfly (Hamilton 1990), moth (Nilsson et al. 1990), bee (Hamilton 1990) and bird pollination (Sobrevilla et al. 1983; Ree 1997). Anemophily is rare and restricted to more advanced members (Bawa \& Beach 1983).

The genus Spermacoce L. comprising 275 species of perennial or annual herbs is distributed in tropical and sub-tropical America, Africa, Australasia and Australia (Dessein et al. 2006). In India, three Spermacoce species, Spermacoce stricta L.f., Spermacoce ocymoides Burm.f. and Spermacoce hispida L. have been reported by Hooker (1881) and other early authors of Indian Floras. Sivarajan et al. (1987) reported that Spermacoce has nine species in India but they named only seven species, Spermacoce confusa Rendle., Spermacoce podocephala DC., Spermacoce 
mauritiana Gideon., Spermacoce pusilla Wall., Spermacoce latifolia Aubl., Spermacoce hispida L. and Spermacoce articularis L. Deb \& Dutta (1984) mentioned that these species are important constituents of herbaceous layer in open habitats, roadsides and agricultural fields. Dessein et al. (2008) stated that the taxonomy of many species of Spermacoce is still in great confusion, especially for paleotropical species. Further, these authors explained the use of certain characters such as general habit, indumentum features, leaf morphology, inflorescence position, calyx and corolla morphology, and types of fruit dehiscence for species delimitation within Spermacoce. Dessein et al. (2005) reported that the Spermacoce species producing small pollen grains might be adapted to specific pollinators and such species bear flowers with very short corolla tubes and the anthers and style included in the tube. In most other Spermacoce species the anthers and style are exserted; those species with short tubes and included anthers and style have different pollen vectors. Punt (1986) stated that variation in sexine ornamentation of pollen grains may indicate differences in pollinators. In general, psilate pollen grains are considered to be adapted to windpollination or beetles, while grains with a rough surface are typical for insect-pollinated species. Machado \& Loiola (2000) reported that Spermacoce is apparently an entomophilous genus. Vaes et al. (2006) mentioned that Spermacoce flowers are hermaphrodite with homostyly or heterostyly, entomophilous and pollination mechanism is conspicuously specialized in that it exhibits passive pollen presentation involving stylar modification or unspecialized with active pollen presentation involving only anthers. These studies suggest that pollination ecology of individual species of Spermacoce has not been studied. Since there is no information on any aspect of pollination ecology in Spermacoce species in general and S. hispida, $S$. articularis and $S$. pusilla in particular, the present study was contemplated to provide detailed information on their pollination ecology to understand their invasive ability as weeds. Further, certain taxonomic information on S. hispida and $S$. articularis is also provided due to confusion in classifying them as different species.

\section{Material and methods}

The seasonal annual herbs, S. hispida, S. articularis and S. pusilla were selected for study during
2014-2016 in Visakhapatnam and its surroundings, Andhra Pradesh, India $\left(17^{\circ} 42^{\prime} \mathrm{N}\right.$ Latitude and $82^{\circ} 18^{\prime} \mathrm{E}$ Longitude). The inflorescence type and the number of flowers per inflorescence were noted using twenty individual plants. Ten inflorescences on five individual plants were tagged prior to commencement of their flowering and followed daily for recording the flowering duration of the inflorescence. Twenty five fresh flowers from five individual plants for each species were used to record the floral details such as flower shape, colour, odour, sex, symmetry, floral mechanism, calyx, corolla, stamens and style and stigma, ovule number, fruit and seed characters in order to give clarity to certain taxonomic characters especially for S. hispida and S. articularis. These characters were used to classify two morphs in S. hispida. Ten inflorescences from five individual plants, which have not initiated flowering were tagged and followed daily to record the duration of flowering, anthesis schedule and the timing of anther dehiscence. Twenty five fresh flowers from five individual plants were used to record the floral morphological details. Twenty mature, but undehisced anthers from ten individual plants were collected from different plants and examined for pollen output per flower and pollen-ovule ratio as per the procedure described in Dafni et al. (2005) and Cruden (1977). Ten flowers each from five individuals were used to test stigma receptivity. It was tested with hydrogen peroxide from mature bud stage to flower closure/drop as per Dafni et al. (2005). Further, the receptivity was also observed visually whether the stigma is shiny, wet or changing colours or withering. Nectar volume, sugar concentration, sugar content, sugar types, sugar energy/flower/day and amino acids were examined for S. hispida and S. articularis as per the protocols described in Dafni et al. (2005) and Heinrich (1975). The thrips found in flowers were very common in the study area and they were identified as per the key provided in Mound et al. (1998). Insects foraging at the flowers were observed from morning to evening on four different days for their mode of approach, landing, probing behavior and contact with the floral sexual organs. Bees, wasps and flies were identified with the representative specimens available with the Department of Environmental Sciences, Andhra University, Visakhapatnam. Butterflies were identified by consulting the books of Kunte (2007). The foraging visits of insects were recorded using $2 \mathrm{x}$ $2 \mathrm{~m}$ area of flowering patch for $10 \mathrm{~min}$ at each 
hour for the entire day on four different days in each year and the data was pooled up and tabulated to record the foraging pattern and the percentage of visits made by them. The pollen/nectar collection behaviour of insects was carefully observed to assess their role in effecting pollination. Ten specimens of each insect species were captured during peak foraging period and brought to the laboratory. Each specimen was washed in ethyl alcohol, stained with aniline-blue on a glass slide and then the pollen grains on the slide were observed under microscope to count the number of pollen grains present. From this, the average number of pollen grains carried by each insect species was calculated to know the pollen carryover efficiency. Plants that have not initiated flowering were tagged and followed to record fruit and seed set rate in open-pollinations. Fruit maturation period, the fruit and seed morphological characteristics were recorded to evaluate their adaptations for dispersal by different means. Further, the seed dispersal modes were examined in the field. The aspects of seed germination and establishment of populations were observed briefly in the field.

\section{Results}

\section{Spermacoce hispida L.}

\section{Plant phenology}

The plant is an erect annual herbaceous weed, branched, sub-shrubby with terete or obscurely 4angled stem. It grows commonly in open, dry rocky, gravelly and sandy soils during rainy and winter season. The plants that grow concurrently in its association include Antigonon leptopus Hook. \& Am. (Polygonaceae), Acalypha indica L. (Euphorbiaceae) and Pedalium murex L. (Pedaliaceae); together these species form a thick blanket covering the ground. S. hispida is bimorphic, classed as morph 1 and 2 plants and show variation in certain characters of stem, leaf and flowers. Morph 1 is common compared to morph 2 plants and they occur intermingled in the same habitat. In both, the stem is green initially and purplish later as the plant ages; it is ascending and covered with hairs but in morph 1 plants, the hair is long, spreading and pilose in nature while it is much reduced in morph 2 plants. The inter-nodal length is $2.50 \pm 1.20 \mathrm{~cm}$ in morph 1 and $3.85 \pm$ $1.02 \mathrm{~cm}$ in morph 2 plants. The leaves are $1.96 \pm$ $0.28 \mathrm{~cm}$ long and $1.29 \pm 0.22 \mathrm{~cm}$ wide in morph 1 while they are $2.46 \pm 0.43 \mathrm{~cm}$ long and $1.33 \pm$ $0.20 \mathrm{~cm}$ wide in morph 2 plants. They are invariably and highly flexuous in morph 1 and slightly flexuous in morph 2 plants. The leaves are obovate or oblong in both morphs but it is quite prominent in morph 2.

\section{Flowering phenology and flower morphology}

Plants of both the morphs flower during July-February (Figs. 1a, 2a). The flowers are campanulate and borne commonly in groups of 5-7 and rarely 8-9 clusters in leaf axils (Figs. 1b, 2b-2d). They are stalkless, small, odourless, bisexual, actinomorphic, and $8 \mathrm{~mm}$ long and $7 \mathrm{~mm}$ wide in both the morphs. The calyx with united basehas four 2 $\mathrm{mm}$ long green valvate sepals with pilose hairs. The corolla is tubular, funnel-shaped, pale purplewhite and $4 \mathrm{~mm}$ long but the tube is broad in morph 1 while it is slightly narrow in morph 2 plants. The tube is extended into with 4 oblongovate $3 \mathrm{~mm}$ long petals and covered with fine hairson the back. The stamens are 4, alternipetalous, white filament and anthers, epipetalous, and protrude from the corolla (Fig. 1c). The ovary is bicarpellary, syncarpous, bilocular with a total of two ovules arranged on axile placentation (Figs. $1 \mathrm{f}, 2 \mathrm{~m})$. The style springs up from the center of the flower; both the style and stigma are white, 6 $\mathrm{mm}$ long in morph 1 and $8 \mathrm{~mm}$ long in morph 2 plants. The stigma is bilobed, capitate,erect and extends beyond the height of stamens (Figs. 1e, 2f).

\section{Floral biology}

In both morphs, the flowers open at 07:00 $\mathrm{h}$ and the anthers dehisce in mature bud stage by longitudinal slits. The pollen grains are white, oblatespheroidal, $41.5 \mu \mathrm{m}$, ornamented, semi-wet in both morphs (Figs. 1d, 2e). In morph 1, the grains are 13-colporate, $139.8 \pm 9.1$ per anther and 559.2 \pm 36.6 per flower. In morph 2 , the grains are 12 colporate, $133.1 \pm 8.4$ per anther and $532.4 \pm 33.6$ per flower. The pollen-ovule ratio is $279.5: 1$ in morph 1 and 266:1 in morph 2. In both morphs, the style and stigma are exserted after anthesis; they do not contact the dehisced anthers at any stage during mature bud but there is likelihood of contact between them during flower life due to their close proximity to each other. The stigma is shiny and receptive following anther dehiscence and ceases it by 15:00 $\mathrm{h}$ of the same day. Both the morphs produce the same volume of nectar. A flower produces $0.13 \pm 0.03 \mu \mathrm{l}$ of nectar with $42.40 \% \pm 2.30 \%$ sugar concentration and $0.064 \mathrm{mg}$ 


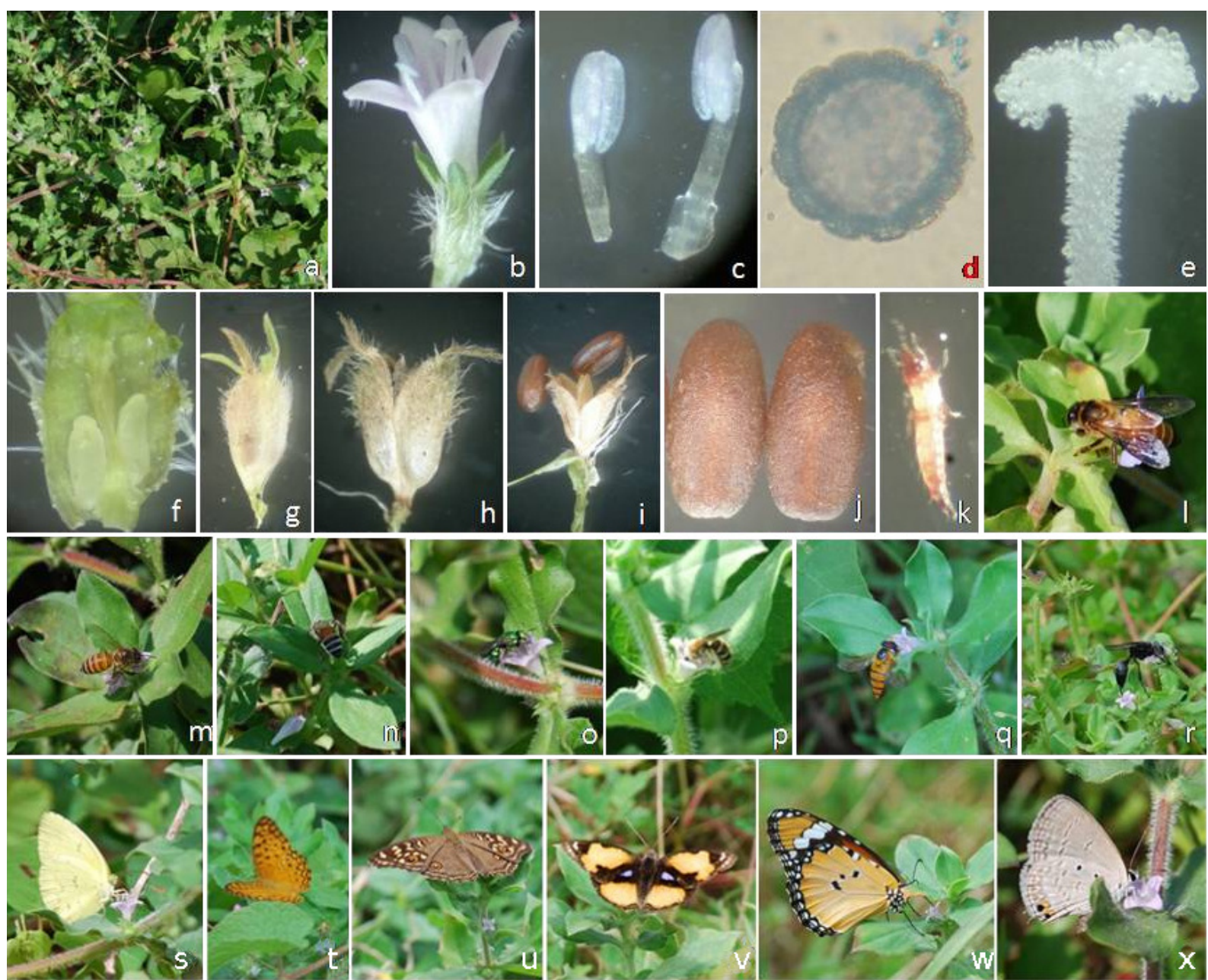

Figura 1. Spermacoce hispida, Forma 1. a: Porción en flor; b: Flor; c: Estambres; d: Grano de polen; e: Estigma; f: Óvulos; g: Fruto maduro; h, i: Dehiscencia explosiva expulsando semillas; j: Semillas; k: Trips; l: Apis dorsata; $\mathbf{m : ~ A p i s ~ c e r a n a ; ~} \mathbf{n}:$ Apis florea; o: Ceratina viridissima; p: Nomia oxybeloides; q: Helophilus sp.; r: avispa no identificada; s: Eurema hecabe; t: Phalanta phalantha; u: Junonia lemonias; v: Junonia hierta; w: Danaus chrysippus; $\mathbf{x}$ : Euchrysops cnejus.

Figure 1. Spermacoce hispida Morph 1. a: Flowering patch; b: Flower; c: Stamens; d: Pollen grain; e: Stigma; f: Ovules; g: Mature fruit; h, i: Explosive fruit dehiscence ejecting seeds; $\mathbf{j}$ : Seeds; k: Thrips; l: Apis dorsata; $\mathbf{m}$ : Apis cerana; $\mathbf{n}$ : Apis florea; o: Ceratina viridissima; $\mathbf{p :}$ Nomia oxybeloides; q: Helophilus sp.; r: Unidentified wasp; s: Eurema hecabe; t: Phalanta phalantha; u: Junonia lemonias; v: Junonia hierta; w: Danaus chrysippus; x: Euchrysops cnejus.

of sugar in morph 1 and $0.17 \pm 0.03 \mu 1$ of nectar with $25.60 \% \pm 4.04 \%$ sugar concentration and $0.049 \mathrm{mg}$ of sugar in morph 2 . The nectar energy per flower is 1.0752 joules in morph 1 and 0.823 joules per flower in morph 2 . The sugar types present in the nectar of both the morphs include sucrose, fructose and glucose. The nectar of morph 1 contains six essential (arginine, histidine, lysine, methionine, threonine, and valine) and nine non-essential (alanine, amino-butyric acid, aspartic acid, cysteine, cystine, glutamic acid, glycine, hydroxy-proline and serine) amino acids. The nectar of morph 2 contains three essential (arginine, tryptophan and valine) and nine nonessential (alanine, aspartic acid, cysteine, glutamic acid, glycine, hydroxyproline, proline, serine and tyrosine) amino acids. The flowers of both the morphs begin to wither away from early evening; some of them fall off on the same day while the remaining ones fall off on the forenoon of the next day. But, the calyx is persistent.

\section{Foraging activity}

The flowers of both the morphs had thrips inside during bud stage and moved out of the flowers at anthesis (Fig. 1k). Thrips were Frankliniella schultzei (Trybom, 1910) and Microcephalothrips abdominalis (Crawford, 1910) (Thysanoptera: Thripidae). They collected pollen and nectar during bud and flower stage and in so doing they effected pollination. The flowers of both the morphs were indiscriminately foraged by the same species of flies, bees, wasps and butterflies during daylight hours. The syrphid fly, Helophilus sp. (Mei- 


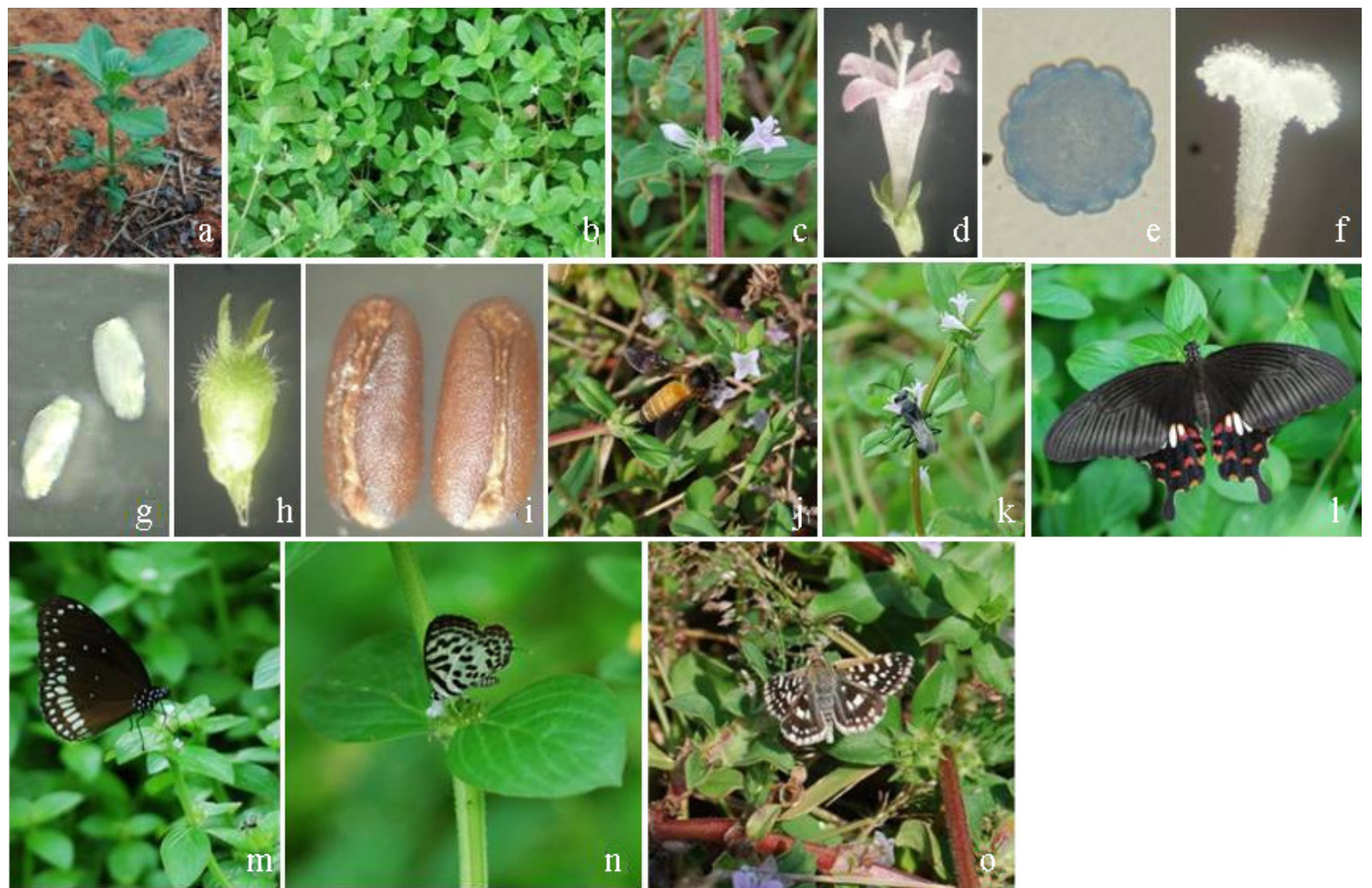

Figura 2. Spermacoce hispida, Forma 2. a: Planta nueva de semilla; b: Porción en flor; c: Producción de flores en axila foliar; d: Flor; e: Grano de polen; f: Estigma; g: Óvulos; h: Fruto; i: Semillas; j: Apis dorsata; k: Avispa no identificada; l: Papilio polytes (hembra); m: Euploea core; $\mathbf{n}$ : Castalius rosimon; o: Spialia galba.

Figure 2. Spermacoce hispida, Morph 2. a: New plant from seed; b: Flowering patch; c: Flower production in leaf axils; d: Flower; e: Pollen grain; f: Stigma; g: Ovules; h: Fruit; i: Seeds; j: Apis dorsata; k: Unidentified wasp; l: Papilio polytes (female); m: Euploea core; n: Castalius rosimon; o: Spialia galba.

gen, 1822) (Fig. 1q) was an occasional forager and attempted to collect nectar during 08:0012:00 h. The bees were Apis dorsata (Fabricius, 1793) (Figs. 11, 2j), Apis cerana (Fabricius, 1793) (Fig. 1m), Apis florea (Fabricius, 1787) (Fig. 1n), Ceratina viridissima (Bingham, 1897) (Fig. 1o) (Apidae) and Nomia oxybeloides (Smith, 1875) (Fig. 1p) (Halictidae) during 06:00-16:00 h. They were regular foragers and collected both nectar and pollen with ease. One unidentified wasp species was the occasional nectar feeder (Figs. 1r, $2 \mathrm{k}$ ). A total of 19 butterfly species were found visiting the flowers of both the morphs regularly and consistently for nectar during 07:00-14:00 h with a gradual increase towards noon and then a gradual decline. They included the Papilionid, Papilio polytes (Linnaeus, 1758) (Fig. 21); the Pierids Eurema hecabe (Linnaeus, 1758) (Fig. 1s), Leptosia nina (Fabricius, 1793), Cepora nerissa (Fabricius, 1775) and Anaphaeis aurota (Fabricius, 1793); the Nymphalids Euploea core (Cramer, 1780) (Fig. 2m), Junonia lemonias (Linnaeus, 1758) (Fig. 1u), Junonia hierta (Fabricius, 1798) (Fig. 1v), Junonia almana (Linnaeus,
1758), Phalanta phalantha (Drury, 1773) (Fig. 1t) and Danaus chrysippus (Linnaeus, 1758) (Fig. $1 \mathrm{w}$ ); the Lycaenids Castalius rosimon (Fabricius, 1775) (Fig. 2n), Zizula hylax (Fabricius, 1775), Euchrysops cnejus (Fabricius, 1798) (Fig. 1x), Everes lacturnus (Godart, 1824), Lampides boeticus (Linnaeus, 1767), Jamides celeno (Cramer, 1775) and Spindasis vulcanus (Fabricius, 1775); and the Hesperiid Spialia galba (Fabricius, 1793) (Fig. 2o). Bees made 31.5\%, wasps $11 \%$, flies $0.5 \%$ and butterflies $57 \%$ of total foraging visits made in a day (Fig. 5). They collected the concealed nectar easily with their proboscis, the length of which is in excess of the length of corolla tube. The small volume of nectar available in the flowers was found to compel the butterflies to make multiple visits to each flower in quest of nectar.

All these insect species while collecting forage invariably had contact with the capitate stigma and dehisced anthers lying just below. Such physical contact between the insects and the sex organs of flowers facilitated self- and/or cross-pollination in both the morphs. The body washings of insects for 


\begin{tabular}{lcccc} 
& \multicolumn{4}{c}{ Number of pollen grains } \\
\cline { 2 - 5 } \multicolumn{1}{c}{ Insect species } & N & Range & Mean & S.D \\
\hline Apis dorsata & 10 & $43-107$ & 74.2 & 19.44 \\
Apis cerana & 10 & $26-82$ & 50.3 & 16.97 \\
Apis florea & 10 & $52-116$ & 86.3 & 18.02 \\
Ceratina viridissima & 10 & $24-73$ & 44.7 & 13.25 \\
Nomia sp. & 10 & $11-58$ & 33.4 & 11.19 \\
Unidentified wasp & 10 & $16-35$ & 24.9 & 5.73 \\
Helophilus sp. & 10 & $15-32$ & 23.7 & 6.40 \\
Eurema hecabe & 10 & $23-64$ & 37.4 & 11.48 \\
Leptosia nina & 10 & $12-31$ & 20.6 & 4.92 \\
Cepora nerissa & 10 & $17-42$ & 28.4 & 8.11 \\
Anaphaeis aurota & 10 & $10-38$ & 23.9 & 8.06 \\
Phalanta phalantha & 10 & $22-47$ & 31.8 & 7.38 \\
Junonia lemonias & 10 & $34-69$ & 45.3 & 10.00 \\
Junonia hierta & 10 & $18-45$ & 31.7 & 7.82 \\
Junonia almana & 10 & $15-53$ & 32.9 & 11.39 \\
Danaus chrysippus & 10 & $27-64$ & 43.8 & 11.76 \\
Castalius rosimon & 10 & $12-31$ & 19.8 & 5.38 \\
Zizula hylax & 10 & $9-28$ & 18.1 & 5.37 \\
Euchrysops cnejus & 10 & $16-39$ & 25.5 & 6.40 \\
Everes lacturnus & 10 & $20-45$ & 29.1 & 7.81 \\
Lampides boeticus & 10 & $13-30$ & 20.2 & 5.05 \\
Jamides celeno & 10 & $15-34$ & 23.6 & 5.31 \\
Spindasis vulcanus & 10 & $14-40$ & 26.7 & 8.40 \\
Spialia galba & 10 & $11-28$ & 19.8 & 4.97 \\
& & & &
\end{tabular}

Tabla 1. Polen registrado en lavados del cuerpo de los insectos en Spermacoce hispida (Forma 1).

Table 1. Pollen recorded in the body washings of insects on Spermacoce hispida (Morph 1).

\begin{tabular}{lcccc} 
& & \multicolumn{3}{c}{ Number of pollen grains } \\
\cline { 2 - 5 } \multicolumn{1}{c}{ Insect species } & N & Range & Mean & S.D \\
\hline Apis cerana & 10 & $18-76$ & 41.6 & 18.01 \\
Apis florea & 10 & $27-103$ & 58.4 & 25.76 \\
Ceratina viridissima & 10 & $15-65$ & 32.2 & 16.64 \\
Nomia sp. & 10 & $20-57$ & 34.6 & 11.22 \\
Unidentified wasp & 10 & $9-43$ & 21.3 & 9.74 \\
Helophilus sp. & 10 & $12-42$ & 24.9 & 18.06 \\
Papilio polytes & 10 & $13-54$ & 26.8 & 13.27 \\
Eurema hecabe & 10 & $20-58$ & 35.4 & 11.10 \\
Leptosia nina & 10 & $15-45$ & 27.6 & 9.53 \\
Cepora nerissa & 10 & $13-36$ & 20.7 & 6.84 \\
Anaphaeis aurota & 10 & $9-44$ & 22.8 & 10.13 \\
Phalanta phalantha & 10 & $23-51$ & 34.9 & 8.88 \\
Junonia lemonias & 10 & $21-75$ & 45.4 & 16.29 \\
Junonia hierta & 10 & $18-60$ & 36.6 & 14.17 \\
Junonia almana & 10 & $12-47$ & 27.3 & 12.18 \\
Danaus chrysippus & 10 & $26-68$ & 43.4 & 11.49 \\
Euploea core & 10 & $21-65$ & 37.9 & 12.54 \\
Castalius rosimon & 10 & $14-42$ & 26.6 & 8.85 \\
Zizula hylax & 10 & $13-35$ & 21.8 & 6.47 \\
Euchrysops cnejus & 10 & $9-33$ & 23.4 & 6.18 \\
Everes lacturnus & 10 & $10-42$ & 26.7 & 9.56 \\
Lampides boeticus & 10 & $12-30$ & 19.9 & 4.94 \\
Jamides celeno & 10 & $15-37$ & 24.2 & 5.89 \\
Spindasis vulcanus & 10 & $22-45$ & 30.8 & 6.33 \\
Spialia galba & 10 & $10-31$ & 19.7 & 5.74
\end{tabular}

Tabla 2. Polen registrado en lavados del cuerpo de los insectos en Spermacoce hispida (Forma 2).

Table 2. Pollen recorded in the body washings of insects on Spermacoce hispida (Morph 2).
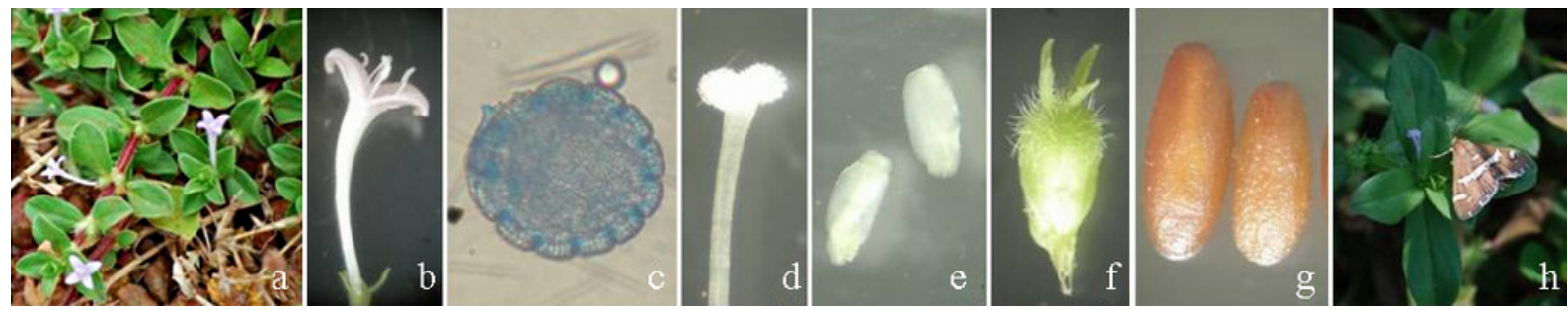

Figura 3. Spermacoce articularis a: Porción en flor; b: Flor; c: Grano de polen; d: Estilo y estigma; e: Óvulos; f: Fruto; g: Semillas; h: Polilla no identificada acercándose a la flor.

Figure 3. Spermacoce articularis a: Flowering patch; b: Flower; c: Pollen grain; d: Style and stigma; e: Ovules; f: Fruit; g: Seeds; h: Unidentified moth approaching the flower.

pollen grain deposits indicated that bees carried the highest number of pollen grains than all other insects from both the morphs substantiating their role in pollination (Tables 1,2).

\section{Fruiting ecology}

In both the morphs, the fruit is a non-fleshy $6 \mathrm{~mm}$ long capsule with hairs on upper half and dehisces septicidally in explosive manner releasing seeds into the air (Figs. 1g-1i, 2h) which are then carried away by the prevailing wind and also dispersed by gravity. Further, the seeds are also ejected due to the falling of water drops into the capsule during rainfall and then they are dispersed by flowing water. The seeds are broadly ellipsoid, coarse with rounded ends in morph 1 (Figs. 1j, 2i) while they are slightly and narrowly ellipsoid, slightly coarse with rounded ends in morph 2. In both the morphs, the testa reticulate, closely pitted, dark brown with a longitudinal ventral groove, $3 \times 1.5$ $\mathrm{mm}$. They are exotestal which is an equivalent of the integument epidermis of the ovule in flowering stage. The seeds are dormant and germinate to produce new plants during rainy season.

\section{Spermacoce articularis L.}

\section{Plant phenology}

The plant is an annual prostrate herb which grows to a length of up to $60 \mathrm{~cm}$. It occurs commonly in 
open, dry rocky and gravel places during rainy and winter season. It does not grow in combination with $S$. hispida or any other herbaceous flora. It is branched, sub-shrubby with sharply 4-angled stem covered with minute hair. The stem is green initially and purplish to dark purple later as the plant ages. The inter-nodal length is $2.88 \pm 0.41$ $\mathrm{cm}$. The leaves are generally flat, occasionally wavy or flexuous, and $1.6 \pm 0.16 \mathrm{~cm}$ long and $0.94 \pm 0.21 \mathrm{~cm}$ wide.

\section{Flowering phenology and flower morphology}

The flowering occurs during July-February (Fig. 3a). They are funnel-shaped, and borne commonly in groups 5-6 and rarely 8-9 in the axils of the leaves. The flowers are stalkless, small, odourless, 10-15 mm long, bisexual and actinomorphic (Fig. 3b). The calyx consists of 4 green $2 \mathrm{~mm}$ long narrowly triangular sepals with robust pilose hairs; the sepals are slightly united at the base. The corolla is mauve to purple, tubular, funnellike and $10 \mathrm{~mm}$ long but the tube is very narrow and broad only at the throat. The tube is extended into with 4 oblong-ovate $3 \mathrm{~mm}$ long and $1 \mathrm{~mm}$ wide petals. The corolla is glabrous outside except for a few hairs near lobe apex; on the inside a band of dense moniliform hairs occur near middle of tube. The stamens are 4, alternipetalous, filament and anthers white in colour, epipetalous, 6 $\mathrm{mm}$ long, and protrude slightly out of the corolla throat. The ovary is bicarpellary, syncarpous, bilocular with two ovules arranged on axile placentation (Fig. 3e). The white style springs up from the center of the flower; it is tipped with white bilobed, capitate, erect stigma extending slightly beyond the height of stamens (Fig. 3d).

\section{Floral biology}

The flowers open at $0700 \mathrm{~h}$ and the anthers dehisce in mature bud stage by longitudinal slits. The pollen grains are white, oblate-spheroidal, 12colporate, $41 \mu \mathrm{m}$ (range 41-49 $\mathrm{mm}$ ), ornamented and semi-wet (Fig. 3c). The pollen output per anther is $138 \pm 10.5$ and it averaged to $552 \pm 41.23$ per flower. The pollen-ovule ratio is 276:1. The style and stigma are exserted after anthesis; they do not contact the dehisced anthers at any stage during mature bud but there is a likelihood of contact between them due to their close proximity to each other. The stigma is shiny and receptive following anther dehiscence and ceases by about $1500 \mathrm{~h}$ of the same day. The nectary disc is bipartite and produces $0.85 \pm 0.14 \mu \mathrm{l}$ of nectar per flower; the nectar sugar concentration is $24.33 \% \pm$
$2.58 \%$; the total sugar content per flower is 0.224 $\mathrm{mg}$. The nectar energy per flower is 3.76 joules. The sugar types in the nectar include sucrose, fructose and glucose. The nectar contains two essential (arginine and threonine) and nine nonessential (alanine, amino-butyric acid, aspartic acid, cysteine, glutamic acid, glycine, hydroxyproline, proline and serine) amino acids. The flowers begin to wither from early evening; some of them fall off on the same day while the remaining ones on the forenoon of the next day. But, the calyx is persistent.

\section{Foraging activity}

Thrips, Fr. schultzei and Mi. abdominalis (Thysanoptera: Thripidae) collected pollen and nectar during bud and flower stage and in so doing they effected pollination. The flowers were indiscriminately foraged by bees for pollen, butterflies and a moth (unidentified) for nectar during daylight hours. The bees were Ap. cerana, Ap. florea, Ce. viridissima (Apidae) and No. oxybeloides (Halictidae) during 06:00-16:00 h. A total of 11 butterfly species, Eu. hecabe, Le. nina (Pieridae), Ju. lemonias, Ju. hierta, Ju. almana, Da. chrysippus (Nymphalids), Ca. rosimon, Eu. cnejus, Ev. lacturnus, Ja. celeno and Sp. vulcanus (Lycaenidae). An unidentified moth was an occasional forager (Fig. 3h). Bees made 59\% and butterflies $41 \%$ of total foraging visits made in a day (Fig. 5). They collected the concealed nectar with their proboscis, the length of which exceeds the length of corolla tube; however, they required a skill to systematically insert their proboscis into the very narrow tubular corolla to collect nectar. The bees, butterflies and the moth while collecting the forage invariably had contact with the capitate stigma and dehisced anthers lying just below. Such physical contact between the insects and the sex organs of flowers facilitated selfand/or cross-pollination. All insects carried more or less equal number of pollen grains on their bodies during forage collection activity substantiating their role in pollination (Table 3 ).

\section{Fruiting ecology}

Fruit is a non-fleshy $4-5 \mathrm{~mm}$ long capsule with hairs on upper half (Fig. 3f) and dehisces septicidally releasing into the air and are then carried away by the prevailing wind and also by gravity. Further, the seeds are also ejected by the falling of water drops into the capsule during rainfall and then they are dispersed by flowing water. The seeds are dark brown, shining smooth, testa reti- 
culate, narrowly oblong, ventrally shallowly grooved, $2.5 \times 1.2 \mathrm{~mm}$ (Fig. $3 \mathrm{~g}$ ). They are exotestal which is an equivalent of the integument epidermis of the ovule in flowering stage. The seeds are dormant and germinate to produce new plants during rainy season.

\begin{tabular}{lcccc} 
& \multicolumn{4}{c}{ Number of pollen grains } \\
\cline { 3 - 5 } Insect species & N & Range & Mean & S.D \\
\hline Apis cerana & 10 & $25-61$ & 39.5 & 11.07 \\
Apis florea & 10 & $23-104$ & 58.4 & 28.00 \\
Ceratina viridissima & 10 & $31-65$ & 38.5 & 14.54 \\
Nomia sp. & 10 & $14-53$ & 29.6 & 10.98 \\
Eurema hecabe & 10 & $20-51$ & 34.3 & 9.98 \\
Leptosia nina & 10 & $11-38$ & 20.9 & 7.67 \\
Junonia lemonias & 10 & $24-63$ & 43.3 & 11.62 \\
Junonia hierta & 10 & $15-49$ & 29.4 & 9.83 \\
Junonia almana & 10 & $21-50$ & 32.4 & 7.91 \\
Danaus chrysippus & 10 & $24-72$ & 45.3 & 13.97 \\
Castalius rosimon & 10 & $12-45$ & 24.4 & 9.66 \\
Euchrysops cnejus & 10 & $16-48$ & 27.3 & 10.15 \\
Everes lacturnus & 10 & $14-37$ & 23.8 & 6.22 \\
Jamides celeno & 10 & $10-42$ & 23.8 & 9.28 \\
Spindasis vulcanus & 10 & $18-45$ & 29.6 & 7.13 \\
Unidentified moth & 10 & $15-58$ & 32.4 & 12.71
\end{tabular}

Tabla 3. Polen registrado en lavados del cuerpo de los insectos en Spermacoce articularis.

Table 3. Pollen recorded in the body washings of bees on Spermacoce articularis.

\section{Spermacoce pusilla Wall.}

\section{Flowering phenology}

The plant is an uncommon erect annual herb that grows up to $60 \mathrm{~cm}$ in open damp sandy soils and along roadsides. It is multi-stemmed and branches out forming bushy habit. The stem is 4-angled and sparsely pubescent. The leaves are sessile, linearoblong, adaxially densely scaberulous to hispidulous and abaxially glabrous to pilosulous. The plants appear from the seed following the monsoonal rains in June. They grow quickly, flower from July onwards and extend up to February depending on the soil moisture status. But, flowering intensity is confined to September-Octoberperiod (Fig. 4a). A plant flowers for about two months. The inflorescence is terminal and axillary in position with many-flowered clusters forming a spikelike appearance (Figs. 4b, 4c). An inflorescence produces $43.44 \pm 14.76$ flowers intermixed with bracteoles in ten days. The flowers are monomorphic and homostylous.

\section{Flower morphology}

The flowers are sessile, funnel-shaped, and stand out prominently against the foliage (Fig. 4d).
They are small $(4.9 \pm 0.3 \mathrm{~mm}$ long and $2.1 \pm 0.4$ $\mathrm{mm}$ wide), white, odourless, actinomorphic and bisexual. The calyx is glabrescent to densely puberulent and hypanthium portion turbinate. The calyx lobes are four, green, linear-lanceolate and 0.6-1.2 $\mathrm{mm}$ long. The corolla is white, funnelshaped (2.7 $\pm 0.4 \mathrm{~mm}$ long), tubular part glabrous and the lobes are linear-lanceolate, $0.8-1.5 \mathrm{~mm}$ long, pubescent both outside and inside. The stamens are four, white, exserted, epipetalous and alternipetalous; the filaments are slender with $1 \mathrm{~mm}$ long creamy white dithecous anthers, dithecous and stand in close proximity to the stigma. The ovary is bicarpellary, bilocular, syncarpous with two ovules on septal placentation (Figs. 4e, 4f) and together with style and stigma it is $3.8 \pm 0.4$ $\mathrm{mm}$ long. The style and stigma are white and spring up from the center of the flower; the style is $2.4 \pm 0.5 \mathrm{~mm}$ long and terminated with a pubescent bifid stigma that stands almost at the height stamens and in close proximity with the anthers.

Floral biology

The flowers open during 0700-0800 $\mathrm{h}$ and the anthers dehisce just before anthesis by longitudinal slits. The pollen grains are white, powdery, oblatespheroidal, 8 to 10 apertures, zonocolporate, wall ornamentation, perforate, sexine granulate and 34 $\pm 2.4 \mu \mathrm{m}$ in size. The pollen output per anther is $210 \pm 29.93$ and per flower is $842 \pm 117$. The pollen-ovule ratio is $421: 1$. The close proximity between the stigma and anthers facilitates autonomous selfing during flower life. The stigma is wet, shiny and receptive during anthesis and the receptivity ceases at $1700 \mathrm{~h}$ of the same day. The nectary disc present around the ovary secretes nectar in traces only. The flowers close back partially at 18:00 $\mathrm{h}$. The petals, stamens, style and stigma fall off on the next day while the calyx gradually bulges into fruiting calyx.

\section{Foraging activity}

Thrips Fr. schultzei and Mi. abdominalis (Thysanoptera: Thripidae) collected pollen and nectar during bud and flower stage and in so doing they effected pollination. The flowers were indiscriminately foraged by the bee for pollen, Ap. florea (Apidae), the fly, Helophilus sp. (Syrphidae) (Fig. 41) and the butterflies, Eu. hecabe (Pieridae) (Fig. 4m), Ca. rosimon (Lycaenidae) (Fig. 4n), Pelopidas mathias (Fabricius, 1798) (Fig. 4o) and Borbo cinnara (Wallace, 1866) (Fig. 4p) (Hesperiidae) for nectar during 08:00-15:00 $\mathrm{h}$ with concentrated activity during 09:00-11:00 h. Bees made 24\%, 

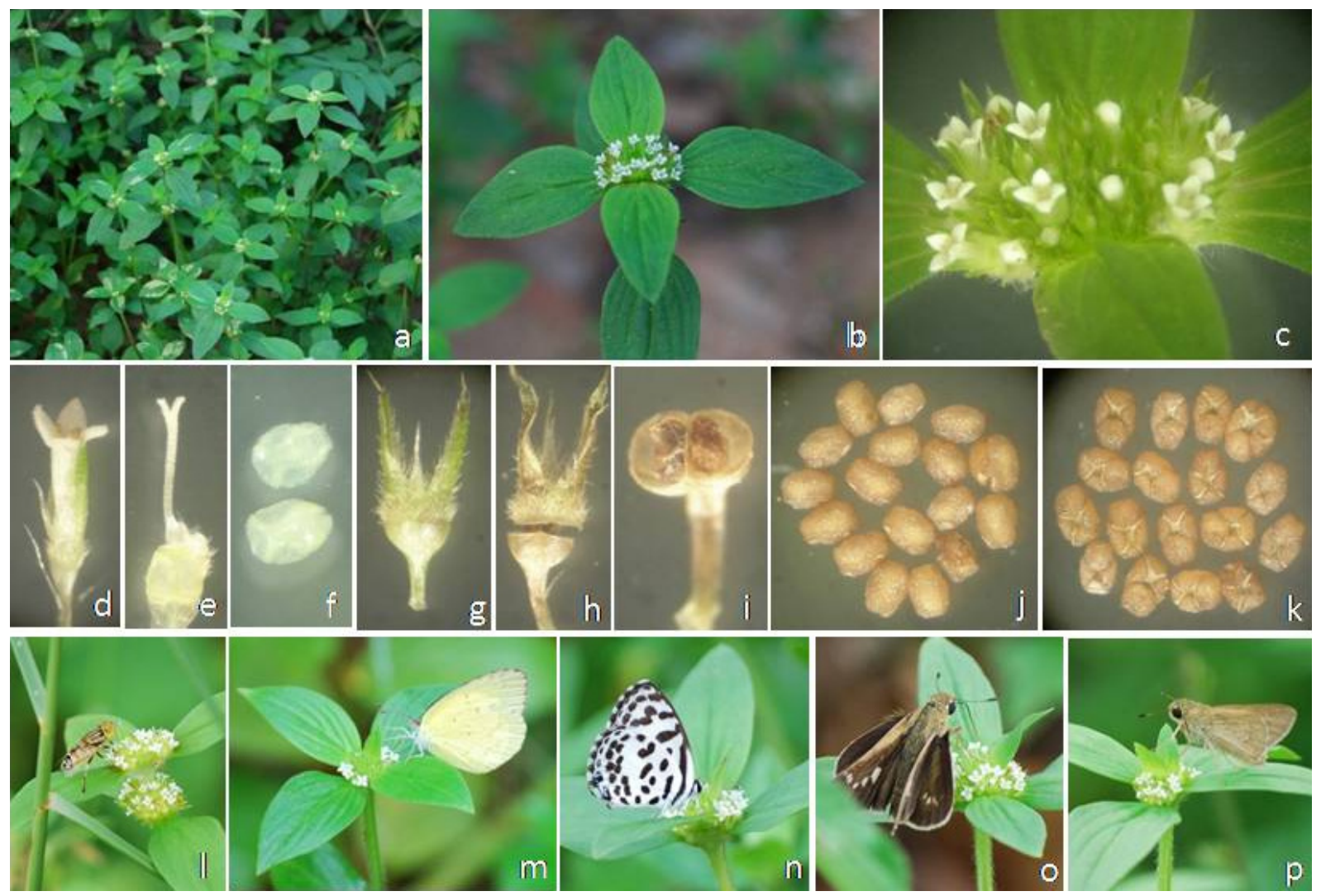

Figure 4. Spermacoce pusilla. a: Porción en flor; b, c: Inflorescencia en flor; d: Flor; e: Ovario, estilo y estigma; f: Óvulos; g: Fruto; h: Fruto con dehiscencia circuncisa ; i: Fruto con 2 semillas; j, k: Semillas; l: Helophilus sp.; m: Eurema hecabe; n: Castalius rosimon; o: Pelopidas mathias; p: Borbo cinnara.

Figure 4. Spermacoce pusilla. a: Flowering patch; b, c: Flowering inflorescence; d: Flower; e: Ovary, style and stigma; f: Ovules; g: Fruit; h: Circumscissile fruit dehiscence; i: 2-seeded fruit; j, k: Seeds; l: Helophilus sp.; m: Eurema hecabe; n: Castalius rosimon; o: Pelopidas mathias; p: Borbo cinnara.

the fly $14 \%$ and butterflies $62 \%$ of total foraging visits made in a day (Fig. 5). The bees and butterflies being regular foragers made multiple visits to the same flowers/inflorescences of different conspecific plants in quest of more forage effecting both self- and cross-pollination. The occasional fly forager also visited the plants in the same way to collect nectar since the latter is produced in traces only and it is mostly consumed by thrips and then by regular foragers. All these insects while collecting nectar from the flowers invariably contacted the stamens and stigma mostly with their tongue/proboscis which resulted in pollination. While probing and collecting the forage from the flowers, they contacted the stigma and stamens effecting pollination. The mean number of pollen grains recorded by each insect species based on body washings of these insects collected from flowers is sufficient to state that all insects carry pollen to different extents with the honey bee carrying the highest number of pollen grains suggesting their role as pollinators (Table 4).

\begin{tabular}{lcccc} 
& \multicolumn{4}{c}{ Number of pollen grains } \\
Insect species & N & Range & Mean & S.D \\
\hline Apis florea & 10 & $38-113$ & 59.1 & 22.08 \\
Helophilus sp. & 10 & $11-46$ & 28.1 & 11.09 \\
Eurema hecabe & 10 & $23-61$ & 41.1 & 12.11 \\
Castlius rosimon & 10 & $15-64$ & 37.9 & 16.12 \\
Pelopidas mathias & 10 & $13-41$ & 25.4 & 8.41 \\
Borbo cinnara & 10 & $20-51$ & 33.1 & 9.96
\end{tabular}

Tabla 4. Polen registrado en lavados del cuerpo de los insectos en Spermacoce pusilla.

Table 4. Pollen recorded in the body washings of bees on Spermacoce pusilla.

\section{Fruiting ecology}

Fruits made in three weeks. The natural fruit set rate $95.66 \%$ while seed set rate is $91.23 \%$. The fruits are non-fleshy oblong to ellipsoid, bilocular, membranous, $2 \times 1.5 \mathrm{~mm}$ capsule, glabrescent at base and glabrescent to densely hirtellous near apex (Figs. 4g, 4i). They dehisce by circumscissile lid to disperse the seeds (Fig. 4h); in this dehiscence mode, the fruit pericarp breaks horizontally and then the seeds slip and fall to the ground or 
are carried away by the prevailing wind. Further, the seeds are also ejected by the falling of water drops into the capsule during rainfall and then they are dispersed by flowing water. The seeds are pale brown, $2 \times 0.5 \mathrm{~mm}$, oblong-ellipsoid with rounded ends, smooth, shiny and grooved ventrally (Figs. 4j, 4k). Seeds are dormant and germinate only during rainy season to produce new plants.

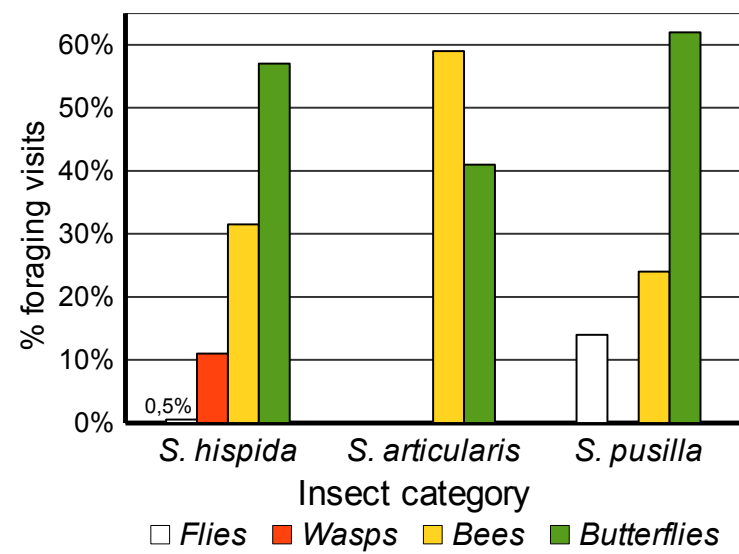

Figura 5. Porcentaje de visitas de distintas categorías de insectos. Figure 5. Percentage of foraging visits of different categories of insects.

\section{Discussion}

\section{Taxonomic aspects of $S$. hispida and $S$. articularis}

The present study revealed that the nectar characters are useful to differentiate $S$. hispida and $S$. articularis. The nectar volume, sugar content and energy is significantly less in S. hispida when compared to that in $S$. articularis. However, the nectar sugar concentration is almost same in both the species. Both the species produce both essential and non-essential amino acids in their nectar. The essential amino acids arginine and threonine are common to both the species; but $S$. hispida also produces histidine, lysine, methionine, tryptophan and valine. The non-essential amino acids alanine, aspartic acid, butyric acid, cysteine, glutamic acid, glysine, hydroxyproline, proline and serine are common to both species but $S$. hispida also produces cystine and tyrosine. Therefore, the differences in nectar characters can be used to differentiate these two species.

In this study, habit, leaf morphology, corolla and seed characters have been used to distinguish
S. hispida from $S$. articularis. $S$. hispida is an erect herb and a successful weed while $S$. articularis is a prostrate herb and is not a weed. Both the species grow in open, rocky gravelly and sandy soils but $S$. hispida habitat is semi-moist and it grows along with other plants such as $A c$. indica, Pe. murex and An. leptopus while S. articularis grows in completely dry soils where other plants do not grow. S. hispida forms extensive patchy populations while $S$. articularis forms limited patchy population. In both the species, the stem is 4-angled but it is obscurely 4-angled in $S$. hispida while it is sharply 4-angled in S. articularis. In both, the stem is green in young plants while it is purplish in mature plants and hence this colour character is not important in species delimitation. The length between nodes of the stem is short in S. articularis and longer in S. hispida. Similarly, the leaves are small, flat or wavy or flexuous in $S$. articularis while they are longer and highly flexuous in S. hispida. The corolla is campanulate, small and the tubular part is spacious in S. hispida while it is funnel-shaped, prominently long and the tubular part is very narrow in S. articularis. The ovules are two in both the species which however, differ in fruit and seed size. The fruit is large in S. hispida and smaller in $S$. articularis. The seed is broadly ellipsoid, coarse and closely pitted in S. hispida while it is smaller, narrowly oblong, shining smooth and testa reticulate. Sivarajan \& Vasudevan Nair (1986) briefly provided certain of these features relating to habit, stem, leaves, flowers, fruits and seeds useful in identifying $S$. hispida and $S$. articularis. The present study also indicates that these features are important taxonomic characters in identifying S. hispida and S. articularis. The seedcoat pattern, the prostrate form with non-flexuous leaves and long tubular flowers of $S$. articularis, display a more closely related seed-coat pattern to S. hispida (Shu-Miaw \& Sivarajan 1989). Pollen characters are alike in both the species except the number of colpi. The pollen grains are characteristically pluricolporate; they are 12-13 colporate in $S$. hispida while they are 12-colporate in $S$. articularis. The pluri-colporate condition appears to be an evolved character to facilitate germination. Dessein et al. (2005) explained the function of these pollen grains using harmomegathy mechanism. It is a process by which pollen grains change in shape to accommodate variations in the volume of the cytoplasm caused by changes in 
hydration. These authors also explained that Spermacoce species with short corolla tubes and included anthers and style are adapted for different pollen vectors. Punt (1986) stated that variation in sexine ornamentation of pollen grains may indicate differences in pollinators. The psilate pollen grains are considered to be adapted to wind or beetle pollination while those with a rough surface are typical for insect-pollinated species. In $S$. hispida and $S$. articularis, the pluricolporate condition of pollen grains is certainly an adaptation to facilitate germination and subsequent fertilization. The rough surface of pollen grains is also an adaptive character for entomophily. In both the species, the pollen-ovule ratio is nearly the same; they show the same schedules in the timing of anthesis, anther dehiscence and stigma receptivity, and also in the duration of flower life. These functional characters of flowers may indicate the presence of the same sexual and breeding system (Cruden 1977).

Sivarajan \& Vasudevan Nair (1986) reported that there are nine Spermacoce species in India of which $S$. hispida is distributed throughout the country while the distribution range of $S$. articularis is still unknown. These authors also noted $S$. hispida is highly polymorphic and exhibits two distinct entities. But, they have not provided any details to distinguish different morphs in this species. The present study identified two distinct morphs of S. hispida based on stem, leaf and flower characters; both occur closely in the same habitats and grow successfully. The plant form with the morphological characters such as the presence of long pilose hair on the stem, short inter-nodal distance, small and highly flexuous leaves, spacious corolla tube, and broadly ellipsoid and coarse seed has been named as morph 1 . The other plant form with the morphological characters such as the presence of short pilose hair on the stem, long inter-nodal distance, small and slightly flexuous leaves, slightly narrow corolla tube, and slightly and narrowly ellipsoid and slightly coarse seed has been named as morph 2 . The morph 1 is the most common form when compared to the other one. The two morphs with perennating heavier rootstock, the more robust habit, and the denser inflorescences may be indicative of their polyploid origin. In line with this, Dessein et al. (2008) documented that such characters relate to polyploid origin and they are found in Spermacoe hockii (De Wild.) Dessein.
Further, S. hispida morphs show variation in seed characters; morph 1 seeds are broadly ellipsoid and coarse with rounded ends while they are slightly and narrowly ellipsoid, slightly coarse with rounded ends in morph 2 . A slight variation exists in sugar and its energy content in the nectar of both the morphs of $S$. hispida. The nectar essential amino acids arginine and valine are common to both the morphs; histidine, lysine, methionine and threonine occur only in morph 1 while tryptophan only in morph 2 . The nectar non-essential amino acids, alanine, aspartic acid, cysteine, glutamic acid, glysine, hydroxyproline and serine are common to both the morphs; butyric acid occurs only in morph 1 while proline and tyrosine only in morph 2 . The study suggests that the morphs in S. hispida can be distinguished not only by morphological characters but also by nectar characters. Further, Kiehn $(1985 ; 1986)$ stated that diploidy, tetraploidy and hexaploidy occur in Spermacoce species. It is not surprising to find the two distinct morphs reflecting polyploid origin in S. hispida. The occurrence of these two morphs in close proximity to each other in the same habitat enforces cross-pollination between morphs and hence there is more likelihood of morphological and functional variations leading to distinct and intermediate entities in S. hispida in its distribution range. Venkateswarlu et al. (1972) documented that $S$. hispida is a synonym to $S$. articularis. But, S. hispida and S. articularis are two different species; the former is bimorphic and isostylous while the latter is completely monomorphic.

\section{Pollination biology of $S$. hispida, $S$. articularis and S. pusilla}

The genus Spermacoce has been considered to be entomophilous and pollination mechanism is conspicuously specialized in that it exhibits passive pollen presentation involving stylar modification or unspecialized with active pollen presentation involving only anthers (Vaes et al. 2006). Faegri \& van der Pijl (1979) stated that butterfly flowers tend to be actinomorphic while bee or wasp flowers tend to be zygomorphic. Cruden et al. (1983) reported that butterflies, bees, and flies require low-energy and accordingly the flowers pollinated by them produce a low volume of nectar. The flowers of both the morphs of S. hispida and $S$. articularis produce minute volume of sucrosedominant nectar while those of $S$. pusilla produce 
traces of nectar the sugar composition of which is not known. Kingsolver \& Daniel (1979) reported that sugar concentration of $25-28 \%$ in the nectar is indicative of the adaptation of flowers for butterflies while Baker \& Baker (1983) stated that the flowers with higher sugar concentration are adapted for bees. In this study, the nectar sugar concentration of $25 \%$ in the morph 2 of S. hispida and of $24 \%$ in $S$. articularis substantiates this assumption; this sugar concentration optimizes the net energy gain by butterflies. On the contrary, the nectar sugar concentration of $42 \%$ in morph 1 of $S$. hispida is suggestive of its adaptation to bees in preference to butterflies. The nectar energy values do not indicate that $S$. hispida morphs are rewarding but the nectar energy value of $S$. articularis indicates that it is rewarding for bees and butterflies. Field observations also indicate that butterflies and bees are important foragers of all the three species of Spermacoce, but lycaenid butterflies are especially important pollinators for $\mathrm{S}$. pusilla. Flies and wasps in S. hispida and flies in $S$. pusilla play a role in pollination when collect nectar from the flowers occasionally and hence they can be considered as minor pollinators. Therefore, bees and butterflies are primary pollinators for all the three Spermacoce species and their role is substantiated by the record of considerable number of pollen grains on their bodies. Therefore, these species are melittophilous and psychophilous, sensu Faegri and van der Pijl (1979).

In all the three species of Spermacoce, thrips Fr. schultzei and Mi. abdominalis effect mainly self-pollination while feeding on pollen and nectar. Nectar depletion by thrips is likely to compel all foragers to intensify their foraging activity and increase pollination rate across populations. The nectar of $S$. hispida is a source of seven essential amino acids while that of $S$. articularis a source of two essential amino acids for insects. The shortlived flowers in all the three Spermacoce species drive the foraging insects to switch to other floral resources in the late afternoon; these foragers then use Tridax procumbens L., An. leptopus, Pe. murex and Tribulus terrestris L. in the habitat of S. hispida and those foraging on S. articularis and $S$. pusilla fly to nearby areas due to absence of other floral resources in their habitats.

Dessein et al. (2008) stated most Rubiaceae produce three apertures in pollen grains while the derived clades of this family produce more than three apertures. Dessein (2003) noted that the Spermacoce clade is primarily representative of pluri-colporate pollen grains but 3-colporate ones also occur. Muller (1979) mentioned that several factors including flower size, style length, pollen vector size, mineral nutrition, and water supply may cause differences in pollen size in Spermacoce. Further, this author found a correlation between the number of apertures and the pollen size. In the studied species of Spermacoce, the pollen grains are pluri-colporate with 12-13 in $S$. hispida, 12 in S. articularis and 8-10 in S. pusilla. This study substantiates the report of Dessein (2003) that Spermacoce species produce mainly pluri-colporate pollen grains. In these species, the pollen grains are larger and hence contain the larger surface; this finding is in line with the report of Dessein et al. (2005) that large volume requires more apertures. These authors also stated that more colpi accommodate variations in the volume of the cytoplasm caused by changes in hydration and facilitate germination. Since these species grow during wet and winter season, the multiporate pollen grains with large surface area appear to be an adaptation to adjust changes in the volume of cytoplasm in response to changes in humidity levels in the ambient environment. Punt (1986) reported that variation in sexine ornamentation of pollen grains may indicate differences in pollinators. The psilate pollen grains are considered to be adapted for wind or beetle pollination while the pollination grains with a rough surface are typical for insect-pollination. In Spermacoce species, the pollen grains contain wall ornamentation, rough surface and pluri-colporate condition, all of these characters are suggestive of adaptations for insectpollination and accordingly insect-pollinated.

Puff et al. (2005) reported two modes of pollen presentation in Rubiaceae. The first mode involves heterostylous species in which the anthers and stigmas are positioned at different heights and spatially separated in bud as well as flower phase, and hence the anthers act as "pollen presenters". The second mode involves isostylous, protandrous species in which the anthers and stigmas are positioned at the same level and anther shed their pollen onto the stigma in late bud stage. When the flower opens, the style straightens out, lifting the pollen high above the level of the corolla. At this stage, the stigmas are not yet receptive. Pollinators at this stage remove the pollen from the stigma. After a period of time, the 
flowers move onto their female phase; the stigma lobes unfold and become receptive. This transition from a functionally male to a functionally female stage over a period of time drastically reduces the chance of a flower's own pollen germinating on its own stigma. In all the three Spermacoce species, the flowers are isostylous, weakly protandrous and the stamens and stigma are positioned at different heights. In S. hispida and $S$. articularis, the stigma straightens out without any contact with the anthers during flower bud stage but there is a possibility for contact between both the sex organs during flower life due to slight bending on the stigmatic lobes and the extended growth of the staminal filaments. In S. pusilla, the stigma straightens and stands almost at the bottom part of the anthers, the position of which largely facilitates contact between both of them during flower life. Autonomous self-pollination takes place when there is contact between the stigma and stamens in all the three species of Spermacoce. Therefore, Spermacoce species with isostylous and protandrous flowers exhibit a different mode of pollen presentation which is not reported in Rubiaceae so far. This study does not agree with Puff et al. (2005) that isostyly and secondary mode of pollen presentation co-occur. Further studies on this aspect in Rubiaceae members may reveal the presence of other modes of pollen presentation which have not been reported so far in isostylous species.

The study indicates that $S$. hispida is monostylous and bimorphic species. The two morphs have similarities in certain functional characteristics such as the number of colpi of pollen grains, pollen-ovule ratio, and timing of anthesis, anther dehiscence and stigma receptivity and length of flower life. The occurrence of these two morphs in association with each other and their simultaneous flowering together with similar functional characteristics allow breeding between them. The flower visitors effect cross-breeding through their alternate forage collection indiscriminately between morph 1 and 2 plants. The cross-breeding between the two morphs may also form intermediate morphs or even other morphs depending on ploidy and gene shuffling levels (Kiehn 1985; 1986). S. articularis is isostylous, monomorphic and is quite distinct from S. hispida in habitat requirement and taxonomic aspects. But, its flowers attract the same species of bees and butterflies which visit $S$. hispida; however, all species that visit the latter do not utilize $S$. articularis flowers as forage and also the flower visitation rate is comparably low. $S$. pusilla is able to attract only lycaenid butterflies in addition to bee and fly species. All the three plant species with their small ephemeral flowers with a brief period of stigma receptivity and a low pollen-ovule ratio are perfect adaptations for self-pollination while keeping the option open for cross-pollination. The highest natural fruit set rate evidenced in these species is attributable to the success of insect pollination followed by autonomous pollination. The production of only two ovules per flower is an important trait in these species to set highest seed set since the stigma does not require huge deposition of pollen to produce fruits with two seeds.

\section{Seed dispersal in S. hispida, S. articularis and S. pusilla}

Puff et al. (2005) reported that fruits of Rubiaceae are of capsule type and classified into three types: those that split open at maturity, those that break into one-seeded mericarps and those that remain indehiscent. The dehiscent capsule types expose and release the seeds. Anemochorous mode of seed dispersal is very widespread and it is more so in species with winged seeds. Ombrochory mode of dispersal also exists but it is uncommon. It occurs in herbaceous taxa with erect, cup-like capsules. Delprete et al. $(2004,2005)$ reported that Spermacoce species possess septicidal fruits with persistent calyx, commonly dehiscent from the top (basipetally) or exceptionally from the bottom (acropetally). In all the three Spermacoce species, the fruit is a hairy, non-fleshy erect, cup-like capsule and dehisces septicidally (dehisce from the top) in S. hispida and S. articularis while it is in circumscissile manner in $S$. pusilla. Circumscissile mode of dehiscence in the last species is quite surprising and is the first report in the family $\mathrm{Ru}-$ biaceae. In both modes of fruit dehiscence, seeds are ejected into the air and they are then dispersed by gravity, by water drops falling into the dry capsule and by run-off during rain. Therefore, all the three Spermacoce species exhibit anemochory, barochory, ombrochory and hydrochory and these seed dispersal modes collectively enable $S$. hispida to be invasive species, especially in open dry rocky, gravelly and sandy soils which are partly covered with other non-invasive herbaceous species. S. articularis, despite the presence of all these seed dispersal modes is not invasive due to 
its preference for dry soils which are devoid of any vegetative cover for its growth. Similarly, $S$. pusilla is also not invasive due to its preference for open, damp sandy soils for its growth and hence is relatively uncommon and occurs in areas where both S. hispida and S. articularis do not occur. This study indicates that the three species with simultaneous schedules of vegetative growth, flowering, fruiting and seed dispersal appear to have evolved for spatial separation to maximize seed production using local bees and butterflies each year and subsequently to colonize the ecological niches which are favourable for them during growth season. In these species, the plants flower for a few weeks but they appear in flowering at population level for two seasons, wet and winter season. This situation appears to be a function of fixed period of dormancy for individual seeds, and accordingly, the seeds produced early would germinate early while those produced late would germinate late, in effect, the vegetative growth and flowering is extended until the onset of dry season.

\section{References}

Anderson WR. 1973. A morphological hypothesis for the origin of heterostyly in the Rubiaceae. Taxon 22: 537-542.

Baker HG \& Baker I 1983.Floral nectar constituents in relation to pollinator type. In: Handbook of Experimental Pollination Biology (Jones CE \& Little RJ. eds.). New York: Scientific and Academic Editions, pp. 117-141.

Bawa KS \& Beach JH. 1983. Self-incompatibility systems in the Rubiaceae of a tropical lowland wet forest. American Journal of Botany 70: 1281-1288.

Castro CC \& Paulo-Eugenio AMO. 2001. Reproductive biology of the protandrous Ferdinandusa speciosa Pohl (Rubiaceae) in southeastern Brazil. Revista Brasileira de Botanica 24: 167-172.

Castro CC, Oliviera PEAM \& Pimente RMM. 2008. Reproductive biology of the herkogamous vine Chiococca alba (L.) Hitchc. (Rubiaceae) in the Atlantic Rain Forest, SE Brazil. Revista Brasileira de Botânica 31: 317-321.

Coelho P \& Barbosa AAA. 2003. Reproductive biology of Palicourea macrobotrys Ruiz and Pavon (Rubiaceae): a possible case of homostyly in the genus Palicourea Aubl. Revista Brasileira de Botânica 26: 403-413.

Consolaro H, Silva EB \& Oliveira PE. 2005. Variaçao floral e biologia reprodutiva de Manettia cordifolia Mart. (Rubiaceae). Revista Brasileira de Botânica 28: 85-94

Cruden RW. 1977. Pollen-ovule ratios: a conservative indicator of breeding systems in flowering plants.
Evolution 31: 32-46.

Cruden RW, Hermann SM \& Peterson S. 1983.Patterns of nectar production and plant-pollinator coevolution. In: The Biology of Nectaries (Bentley B \& Elias T. eds.). New York: Columbia University Press, pp. 80125.

Dafni A, Kevan PG \& Husband BC 2005. Practical Pollination Biology. Enviroquest Ltd, Cambridge, pp.583.

Davis AP, Rafael G, Diane MB, Markus R, Justin M \& Neil AB. 2009. A global assessment of distribution, diversity, endemism, and taxonomic effort in the Rubiaceae. Annals of the Missouri Botanical Garden 96: 68-78.

Deb DB \& Dutta R. 1984.Revision of the genus Spermacoce (Rubiaceae) in India and adjoining regions. Journal of Economic and Taxonomic Botany 5: 1037-1063

Delprete PG \& Jardim JG. 2012. Systematics, taxonomy and floristic of Brazilian Rubiaceae: an overview about the current status and future challenges. Rodriguesia 63: 101-128.

Delprete PG, Smith LB \& Klein RB 2004. Rubiaceae. Volume 1. Generos de A-G. Alseis ate 19. Galium. In: Flora Illustrada Catarinense (A. Reis. ed.). Itajai, Brazil: Herbario "Barbosa Rodrigues", pp. 1-344.

Delprete PG, Smith LB \& Klein RB 2005. Rubiaceae. Volume 2. Generos de G-Z: 20. Gardenia ate 46. Tocoyena. In: Flora Illustrada Catarinense (A Reis. ed.). Itajai, Brazil: Herbario "Barbosa Rodrigues", pp. 345-843.

Dessein S. 2003. Systematic studies in the Spermacoce (Rubiaceae). Ph.D. Thesis, Katholicke Universiteit Leuven, Belgium.

Dessein S, Harwood R, Smets E \& Robbrecht E. 2005. Pollen of Spermacoce (Rubiaceae) species from the Northern territory of Australia: morphology and taxonomic significance. Australian Systematic Botany 18: 367-382.

Dessein S, Ntore S, Robbrecht E \& Smets E. 2008. Pollen and seeds reveal that Spermacoce thymoidea s.l. (African Rubiaceae, Spermacoceae) represents three endemic or disjunct species from the Zambezian high plateaus. Systematic Botany 29: 130-144.

Dessein S, Rubbrecht E \& Smets E. 2006. A new heterophyllous Spermacoce species (Rubiaceae) from the Marungu highlands (D.R. Congo). Novon 16: 231-234.

Faegri K. \& van der Pijl L. 1979. The Principles of Pollination Ecology. Pergamon Press, Oxford, pp. 244.

Hamilton CH. 1990. Variations on a dystylous theme in a Mesoamerican Psychotria subgenus Psychotria (Rubiaceae). Memoirs of the New York Botanical Garden 55: 62-75.

Heinrich B. 1975. Energetics of pollination. Annual Review of Ecology and Systematics 6: 139-170.

Hooker JD. 1881. The Flora of British India. Vol. 1-7. L. London: Reeve \& Co.

Kiehn M. 1985. Chromosome survey of the Rubiaceae. Annals of Missouri Botanic Garden 82: 398-408.

Kiehn MKM. 1986. Karyologiche Untersuchungen und DNA-Messungen an Rubiaceae und ihre Bedeutung 
fur die Systematik dieser Familie. Dissertation zur Erlangung des Doktorgrades.Formal und Naturwissenschaftlichen. Fakuhat Wien, Universitat Wien.

Kingsolver JG \& Daniel TL.1979. On the mechanics and energetics of nectar feeding in butterflies. Journal of Theoretical Botany 76: 167-179.

Kunte K. 2007. A lifescape of butterflies of peninsular India. Hyderabad: University Press.

Ladd PG. 1994. Pollen presenters in the flowering plants - form and function. Botanical Journal of the Linnean Society 115: 165-175.

Machado IC \& Loiola MI. 2000. Fly pollination and pollinator sharing in two synhronopatric species: Cordia multispicata (Boraginaceae) and Borreria alata (Rubiaceae). Revista Brasileira de Bôtanica 23: 1-13.

Mound LA, Houston KJ, Kibby G \& Kibby G. 1998. Thysanoptera: An identification guide. Oxfordshire: CABI Publishing.

Muller J. 1979. Form and function in angiosperm pollen. Annals of Missouri Botanic Garden 66: 593-632.

Nilsson LA, Petterson B \& Ranaivo J. 1990. "Ixoroid" pollen presentation and pollination by small moths in the Malagasy treelet Ixora platythyrsa (Rubiaceae). Plant Systematics and Evolution 170: 161-175.

Puff C, Chayamarit K \& Chamchumroon V. 2005. Rubiaceae of Thailand. A pictorial guide to indigenous and cultivated genera. Bangkok: Forest Herbarium, National Park, Wildlife and Conservation Department.

Punt W. 1986. Functional factors influencing pollen form. In: Pollen and spores: form and function (Blackmore S \& Ferguson IK, eds.). Linnean Society Symposium Series vol. 12. London: Academic Press, pp. 97-101.

Ree RH. 1997. Pollen flow, fecundity, and adaptative significance of heterostyly in Palicourea padifolia (Rubiaceae). Biotropica 29: 298-308.

Robbrecht E. 1988. Tropical woody Rubiaceae. Opera Botanica Belgica 1: 1-271.

Shu-Miaw C \& Sivarajan VV. 1989. Seed coat micromorphology of some Asiatic Spermacoceae (Rubiaceae). Botanical bulletin of Academia Sinica 30: 1524.

Sivarajan VV \& Vasudevan Nair R. 1986. Taxonomic and nomenclatural notes on the Spermacoce hispida-articularis complex and $\mathrm{S}$. stricta-pusilla complex (Rubiaceae). Taxon 35: 363-369.

Sivarajan VV, Vasudevan Nair R \& Ahmed Kunju TU. 1987. Genus Spermacoce Linn. (Rubiaceae) in India. Proceedings of Indian Academy of Sciences (Plant Sciences) 97: 347-358.

Sobrevila C, Ramirez N \& De Enrech NX. 1983. Reproductive biology of Palicourea fendleri and P. petiolaris (Rubiaceae), heterostylous shrubs of a tropical cloud forest in Venezuela. Biotropica 15: 161-169.

Vaes E, Vrijdaghs A, Smets EF \& Dassein S. 2006. Elaborate petals in Australian Spermacoce (Rubiaceae) species: morphology, ontogeny and function. Annals of Botany 98: 1167-1178.

Venkateswarlu J, Bhairavamurthy PV \& Narasimha Rao P. 1972. The Flora of Visakhapatnam. Hyderabad : Andhra Pradesh Academy of Sciences.

Webb CJ \& Lloyd DG. 1986. The avoidance of interference between the presentation of pollen and stigmas in angiosperms. 2. Herkogamy. New Zealand Journal of Botany 24: 163-178.

Yeo P. 1993. Secondary pollen presentation. SpringerVerlag, Wien, Austria. 